\title{
Cloudy weather may have saved Society Island reef corals during the 1998 ENSO event
}

\author{
Peter J. Mumby ${ }^{1, *}$, John R. M. Chisholm ${ }^{2}$, Alasdair J. Edwards ${ }^{1}$, Serge Andrefouet ${ }^{3}$, \\ Jean Jaubert ${ }^{2,4}$ \\ ${ }^{1}$ Centre for Tropical Coastal Management Studies, Department of Marine Sciences and Coastal Management, \\ Ridley Building, The University, Newcastle upon Tyne NE1 7RU, United Kingdom \\ ${ }^{2}$ Observatoire Océanologique Européen, Centre Scientifique de Monaco, Avenue Saint-Martin, MC 98000, \\ Principality of Monaco \\ ${ }^{3}$ Department of Marine Science, University of South Florida, 140 7th Avenue South, St Petersburg, Florida 33701, USA \\ ${ }^{4}$ Université de Nice, Faculté des Sciences, Campus Calrose, 06108 Nice, France
}

\begin{abstract}
During the 1998 El Niño-Southern Oscillation (ENSO) event, mass coral bleaching in French Polynesia was patchy at a scale of $100 \mathrm{~s}$ of $\mathrm{km}$. Bleaching was extensive in parts of the Tuamotu archipelago (creating up to 99\% coral mortality) but extremely mild in the Society Islands (Tahiti, Moorea), ca $350 \mathrm{~km}$ to the south-west, despite sea surface temperature (SST) anomalies being of similar magnitude to previous years in which mass bleaching occurred. We examine whether environmental variables account for this unexpected paucity of bleaching using a 50 yr record of SST, a 17 yr record of daily wind and cloud cover, and a 17 yr record of monthly sun hours. Records from Tahiti reveal that exceptionally high cloud cover significantly reduced the number of sun hours during the summer of 1998. Quadratic discriminant analyses of annual bleaching occurrence based on up to 3 predictors (cumulative degree heating months, wind speed, and cloud cover during periods of elevated summer SST) only predicted the correct bleaching scenario for 1998 when cloud cover was added to the function. The results demonstrate that the interactive effect of cloud cover can reverse the bleaching predictions of such statistical models. We suggest that reduced radiative stress, resulting from high cloud cover, may have prevented large-scale coral bleaching in 1998.
\end{abstract}

KEY WORDS: El Niño-Southern Oscillation · Coral bleaching · Climate change · Sea surface temperature anomaly

Resale or republication not permitted without written consent of the publisher

\section{INTRODUCTION}

Coral bleaching refers to the paling of coral tissue brought about by loss of symbiotic dinoflagellate algae (zooxanthellae) and/or their pigments (Glynn 1993, Brown 1997). Although bleaching is a generalised response that may result from a variety of environmental stresses (e.g. low salinity), the term 'mass coral bleaching' has been used to describe large-scale events in which intense bleaching occurs throughout entire reef systems and geographic realms (Glynn 1993, Hoegh-

${ }^{*}$ E-mail: p.j.mumby@ncl.ac.uk
Guldberg 1999). Mass bleaching may result in mass coral mortality (Glynn 1993, Wilkinson 2000). Based on laboratory studies, several authors have suggested that heat and radiative stress interfere with zooxanthellar photosystems (Lesser et al. 1990, Fitt \& Warner 1995, Lesser 1996, Warner et al. 1996, Brown 1997, IglesiasPrieto 1997, Jones et al. 1998, Hoegh-Guldberg 1999). Reduced efficiency of utilising photosynthetic energy (Osmond 1994) occurs when the zooxanthellar photosystem is saturated with photosynthetically active radiation (PAR). Unless excess excitation energy is dissipated (e.g. by the xanthophyll cycle, Brown et al. 1999), photo energy is directed to the creation of harmful 
(e.g. oxygen) free radicals which disrupt photosystems (Lesser et al. 1990, Lesser 1996, Brown 1997, Jones et al. 1998). As Hoegh-Guldberg (1999) summarised, 'Light [..] becomes a liability under conditions of higher than normal temperatures'.

Whilst the laboratory studies listed above are essential in understanding the mechanistic basis of bleaching, there remains a need to breach the gulf in scale between laboratory studies and large-scale geographic patterns of bleaching. For example, experimental manipulations of temperature and/or irradiance may elicit bleaching in individual polyps on a time scale of minutes (Falkowski et al. 1990) but how do such observations relate to mass bleaching at scales of months and perhaps 1000s of $\mathrm{km}$ ? A number of attempts have been made to investigate large-scale correlates of mass bleaching including solar radiation (Fisk \& Done 1985, Gleason \& Wellington 1993), sea surface or sub-surface temperature (e.g. Goreau \& Hayes 1994, Hoegh-Guldberg \& Salvat 1995, Brown et al. 1996, Davies et al. 1996, Jones et al. 1998, Winter et al. 1998, HoeghGuldberg 1999, Wilkinson et al. 1999) and combinations of sea surface temperature (SST) and solar radiation (Harriott 1985, Brown \& Suharsono 1990). Given the success of relating mass bleaching to elevated SST, several initiatives are underway to predict the occurrence of bleaching events using environmental data. NOAA's Hotspot programme, for example, utilises satellite-based measurements of SST to identify thermal anomalies and their duration (Strong et al. $1998^{1}$ ). Here, we examine a long-term meteorological record to provide the first empirical evidence that local patterns of cloud cover may influence the susceptibility of reefs to mass bleaching and subsequent coral mortality during periods of anomalously high SST.

\section{METHODS}

Study site and bleaching context. The Society Islands (e.g. Tahiti and Moorea) are located in French Polynesia at $149.5^{\circ} \mathrm{W}, 17.5^{\circ} \mathrm{S}$. Bleaching episodes have been reported for Tahiti/Moorea in 1983, 1984, 1987, 1991, 1993, and 1994 (Glynn 1984, Salvat 1992, Gleason 1993, Drollet et al. 1994, 1995, Hoegh-Guldberg \& Salvat 1995). The severity of bleaching is difficult to quantify at large (whole reef) scales and therefore the intensity of bleaching has not been determined consistently for each year. All bleaching years except 1993 have been described as 'mass bleaching events', which are defined as involving entire reef systems and geographic realms (Glynn 1993, Hoegh-Guldberg 1999).

\footnotetext{
${ }^{1}$ See also: http://psbsgi1.nesdis.noaa.gov:8080/PSB/EPS/method.html
}

In 1991 and 1994, genus-specific susceptibility (Acropora, Pocillopora, Porites [least]) and severity of bleaching were similar, with at least $90 \%$ of Acropora colonies bleaching in both 1991 and 1994 (Salvat 1992, Gleason 1993, Hoegh-Guldberg \& Salvat 1995). By contrast, Drollet et al. (1995) showed that the 1993 episode was minor relative to that in 1994 (and by implication that in 1991). In Tahiti, the mean proportion of colonies showing signs of bleaching ranged from $7-35 \%$ per site in 1993 to $34-42 \%$ in 1994 (Drollet et al. 1995). Hoegh-Guldberg \& Salvat (1995) reported that 40 to $72 \%$ of all colonies exhibited signs of bleaching in Moorea in 1994. In 1998, the global pattern of mass coral bleaching was the most severe ever recorded and resulted in unprecedented mass coral mortality (Wilkinson et al. 1999). Although mass bleaching occurred in many parts of French Polynesia (e.g. the Tuamotu Archipelago leading to $99 \%$ coral mortality in places, see Mumby et al. 2001) it did not occur in the Society Islands (Wilkinson 2000). Some highly localised occurrences of bleaching were observed around Moorea in 1998 but these were of an even lower intensity than those reported for 1993 (S.A. pers. obs.). A thermal 'threshold' of $29.2^{\circ} \mathrm{C}$ was suggested by Hoegh-Guldberg \& Salvat (1995) and Hoegh-Guldberg (1999) to account for the incidence of bleaching events in the Society Islands.

SST. The Global Sea-Ice and SST data set Version 2.3b (GISST2.3b) for $1^{\circ}$ latitude $\times$ longitude areas was used to examine the 1998 warming anomaly around the Society Islands. The data set was provided by the UK Meteorological Office's Hadley Centre for Climate Prediction and Research. It uses an Empirical Orthogonal Function to interpolate data-voids and provide global coverage (Rayner et al. 1996, Smith et al. 1996). This is a blend of bias-corrected Advanced Very High Resolution Radiometer (AVHRR) satellite-derived SST data and in situ data from 1982 and requires little interpolation (Parker et al. 1995, Rayner et al. 1996). The bias-correction adjusts for differences between oceanic skin temperature as measured by the satellite and in situ bulk SST (Reynolds 1988). To compare anomalies between SST and other variables, records from 1983 to 1999 were subset to provide monthly mean SST and anomalies were identified as departure from the 1983 to 1999 mean for each month. Positive monthly anomalies (i.e. months with elevated temperature) were summed for each year, giving a coarse measure of the total summer positive thermal anomaly.

Wind speed, sun hours and cloud cover. Meteorological data were obtained for Tahiti from 1983 to 1999. Cloud cover (oktas, where 1 okta represents an eighth of the hemispherical sky being occupied by cloud) and wind speed $\left(\mathrm{ms}^{-1}\right)$ were recorded at 13:00 to 14:00 h (local time) from 1983 to 1999. Additional measure- 
ments at 11:00 and 16:00 h were available from 1993 onwards. Cloud cover data at 11:00 and 13:00 to 14:00 h were particularly important since these times fall just either side of the period of maximum down-welling irradiance when the sun is at its maximum altitude (ca 12:10 $\mathrm{h}$ in the critical months of February to April). The total number of sun hours, where light intensity exceeded $120 \mathrm{~W} \mathrm{~m}^{-2}$ (i.e. cloud free or very low cloud cover), were also obtained for each month. Sun hours and afternoon cloud cover were both included in the analysis because sun hours alone do not relate to periods when solar radiation is at its daily maximum. It is important to make this distinction because if sun hours were anomalously high in the early morning and late afternoon but not at noon, then corals might not have experienced anomalous levels of total irradiance. The correlation between monthly sun hours and cloud cover was strong and negative (Pearson $r=-0.74, \mathrm{p}<0.0001$, following Anderson-Darling tests for normality). In the absence of direct PAR measurements at large scales, we suggest that noon cloud cover can be a useful surrogate for maximum daily irradiance at a scale of kilometres.

Monthly anomalies in each variable were calculated as the difference from the 1983 to 1999 monthly mean. A similar approach is used by the NOAA coral bleaching monthly hotspot programme (Strong et al. 1998). To compare the relative magnitudes of anomalies between variables, the data were standardised by expressing each anomaly as a percentage of the mean monthly value between 1983 and 1999. Since the responses of zooxanthellae to changing light intensity can involve short time scales (e.g. minutes, hours, or days; see Falkowski et al. 1990), anomalies in cloud cover were also investigated at a daily scale and at different times of day. Daily anomalies for each time of day were calculated as the difference between mean monthly cloud cover at each time and the daily record.

Interactions between SST anomalies, wind speed and cloud cover. Quadratic discriminant analysis was used to evaluate the interactions between environmental variables and their crude predictive capability for bleaching events. This form of discriminant analysis was chosen because, unlike linear discriminant analysis, it does not require equal covariance matrices among variables (Minitab 1997). Since bleaching is most likely to occur when summer SST is anomalously high (Hoegh-Guldberg 1999, Wilkinson et al. 1999), meteorological data were analysed only for periods where SST anomalies were positive in summer months. Recent work on predicting bleaching from SST 'hotspots' utilises the degree heating weeks (see Footnote ${ }^{1}$ ) which is the sum of weekly positive thermal anomalies $\left({ }^{\circ} \mathrm{C}\right)$ where an anomaly exceeds summer maximum SST. To calculate a similar measure from monthly SST data, incorporating the duration and extent of heating, positive monthly SST anomalies were summed for each year. The discriminant function was built using all years in which SST was anomalously high except 1998. Data for 1998 were then added to the function to examine whether the minor bleaching in 1998 was predicted. Although the severity of bleaching has not been quantified in each year, bleaching was reported to be mild in 1993 (Drollet et al. 1994, 1995) and therefore discriminant analysis was carried out with alternate bleaching states in this year. Sun hours were excluded from the analysis because of cross-correlation with cloud cover.

\section{RESULTS}

The weekly SST bleaching 'threshold' of $29.2^{\circ} \mathrm{C}$ (Hoegh-Guldberg 1999) is shown on the 50 yr time series of monthly SST (Fig. 1) and although we question the usefulness of such thresholds later, it is instructive to use this threshold line in making inter-annual comparisons. Monthly SST exceeded $29.2^{\circ} \mathrm{C}$ for at least 1 mo during each of the 1984, 1991, 1993, and 1994 bleaching events but not during the 1983 or 1987 events. SST was elevated (ca $29.2^{\circ} \mathrm{C}$ ) for a longer period of time (2 mo) in 1998 than in all bleaching years and the maximum monthly SST during bleaching years only exceeded that of 1998 in 1984 and 1991. In situ observations of sea temperature from the fringing reef, barrier reef, and in the channel of Tiahura reef (Moorea) confirm that monthly mean temperature exceeded $29.2^{\circ} \mathrm{C}$ for 2 mo in 1998 (B. Salvat pers. comm.). In short, the SST data suggest that mass bleaching would have been expected in 1998, other factors being equal.

With the exception of 1983, all bleaching years exhibited 2 to 4 mo positive SST anomalies (Fig. 2a). A 2 mo positive SST anomaly was also observed in 1998 (as above). The mean summer (January to April) positive SST anomaly during non-bleaching years was $+0.27^{\circ} \mathrm{C}$, which was significantly less than that $\left(+1.22^{\circ} \mathrm{C}\right)$ in bleaching years (1-tailed Mann-Whitney $U$-test, $\mathrm{p}<0.01)$. However, summer positive SST anomalies (i.e. sum of positive anomalies from the months January to April in each year) varied considerably between years in which bleaching was observed. Specifically, the summer positive SST anomalies during bleaching years were $+0.04^{\circ} \mathrm{C}(1983,1 \mathrm{mo}$ anomaly), $+2.11^{\circ} \mathrm{C}\left(1984,4\right.$ mo anomaly), $+0.62^{\circ} \mathrm{C}(1987$, 3 mo anomaly $),+1.62^{\circ} \mathrm{C}(1991,3$ mo anomaly $),+1.79^{\circ} \mathrm{C}$ (1993, 4 mo anomaly), and $+1.14^{\circ} \mathrm{C}(1994,4$ mo anomaly). The equivalent anomaly in 1998 was $+1.15^{\circ} \mathrm{C}$ (2 mo) which, compared to the anomalies in massbleaching years, was greater than 1983, less than 1991 and similar to 1994 . 


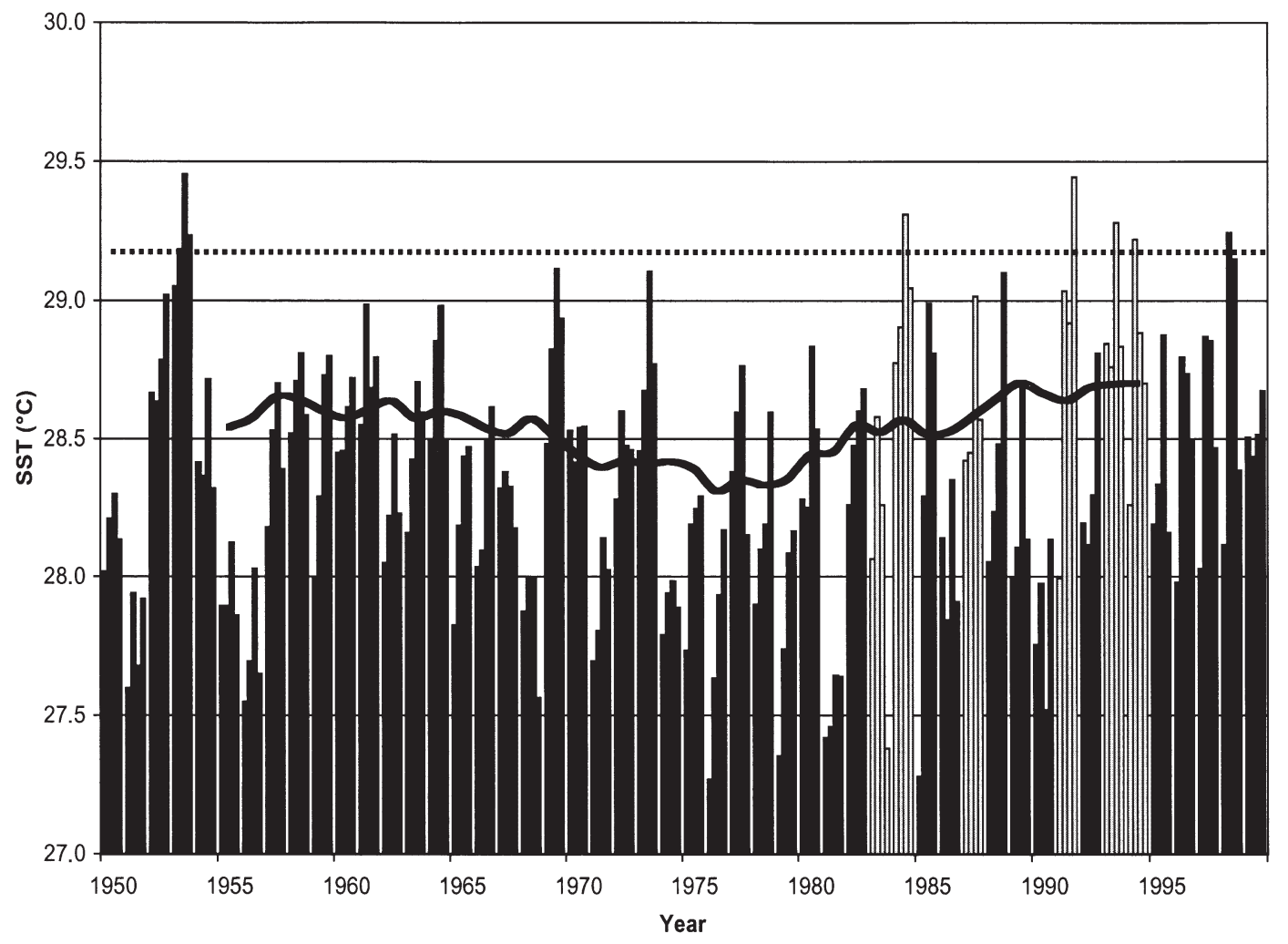

Fig. 1. Monthly sea surface temperature (SST) in the Society Islands, French Polynesia, for January to April. (— -11 yr running mean for SST during the warmest summer month (March), and (.....), thermal bleaching threshold for the Society Islands suggested by Hoegh-Guldberg (1999). Note: Hoegh-Gulberg \& Salvat (1985) first suggested this threshold, but in relation to in situ data at a depth of $14 \mathrm{~m}$ rather than SST data. Bleaching years are indicated by light shading

Wind speed anomalies showed no consistent relationship with the incidence of bleaching years. However, where absolute anomalies were small during bleaching years (e.g. 1983; Fig. 2) the coefficients of variation (COV) of monthly wind speed were high, indicating both very calm and very windy conditions within months (e.g. the mean COV of wind speed between January and April was 66\% in 1983 but 49\% in 1984 to 1999). Wind speeds were consistently high during the 1993 and 1994 bleaching events but showed negative anomalies during 1998 (Fig. 2b).

With the exception of 1983, cloud cover was low and sun hours were high during bleaching events (Fig. 2c,d). In 1998, however, sun hours were the lowest on record for February and cloud cover was consistently high for February to April. For the 2 months in summer 1998 for which data were available, sun hours were significantly less than monthly means (February 1998 sun hours = 100, lower 99\% CL of mean = 171.9 h; March 1998 sun hours $=191$, lower $99 \%$ CL of mean $=212.1 \mathrm{~h}$ ).

Daily cloud cover at 11:00, 13:00 to $14: 00$, and 16:00 h was significantly greater in the summer (February to April) of 1998 than in bleaching years and all other years for which data were available (Fig. 3; Mann
Whitney $U$-tests $\mathrm{p}<0.001)$. It is also instructive to calculate the percentage of days when cloud cover was less than the lower 99\% confidence level for mean cloud cover in each month. For times 11:00, 13:00 to 14:00, and 16:00 $\mathrm{h}$ respectively, the percentage of 'cloudy' days in 1998 was 65, 66, and 67\%. The equivalent percentages of 'cloudy' days, averaged for bleaching years, were 38,48 and $39 \%$ (i.e. ca two-thirds of the number of cloudy days in 1998).

Discriminant analyses generally represented training data faithfully because the minimum internal success of predicting bleaching events from training data was $77 \%$ (Table 1). However, the magnitude of cumulative SST anomaly with and without data on wind speed consistently and incorrectly predicted bleaching to have occurred in 1998. The occurrence of bleaching in 1998 was only predicted correctly (with >99.9\% certainty) once cloud data were incorporated into the function. When the weak bleaching year 1993 was classified as 'non mass-bleaching', the internal predictive capability of the function increased as wind and cloud cover were added. All analyses suggested that bleaching would occur in 1993 and internal accuracy was greatest under this assumption. Ultimately, the 

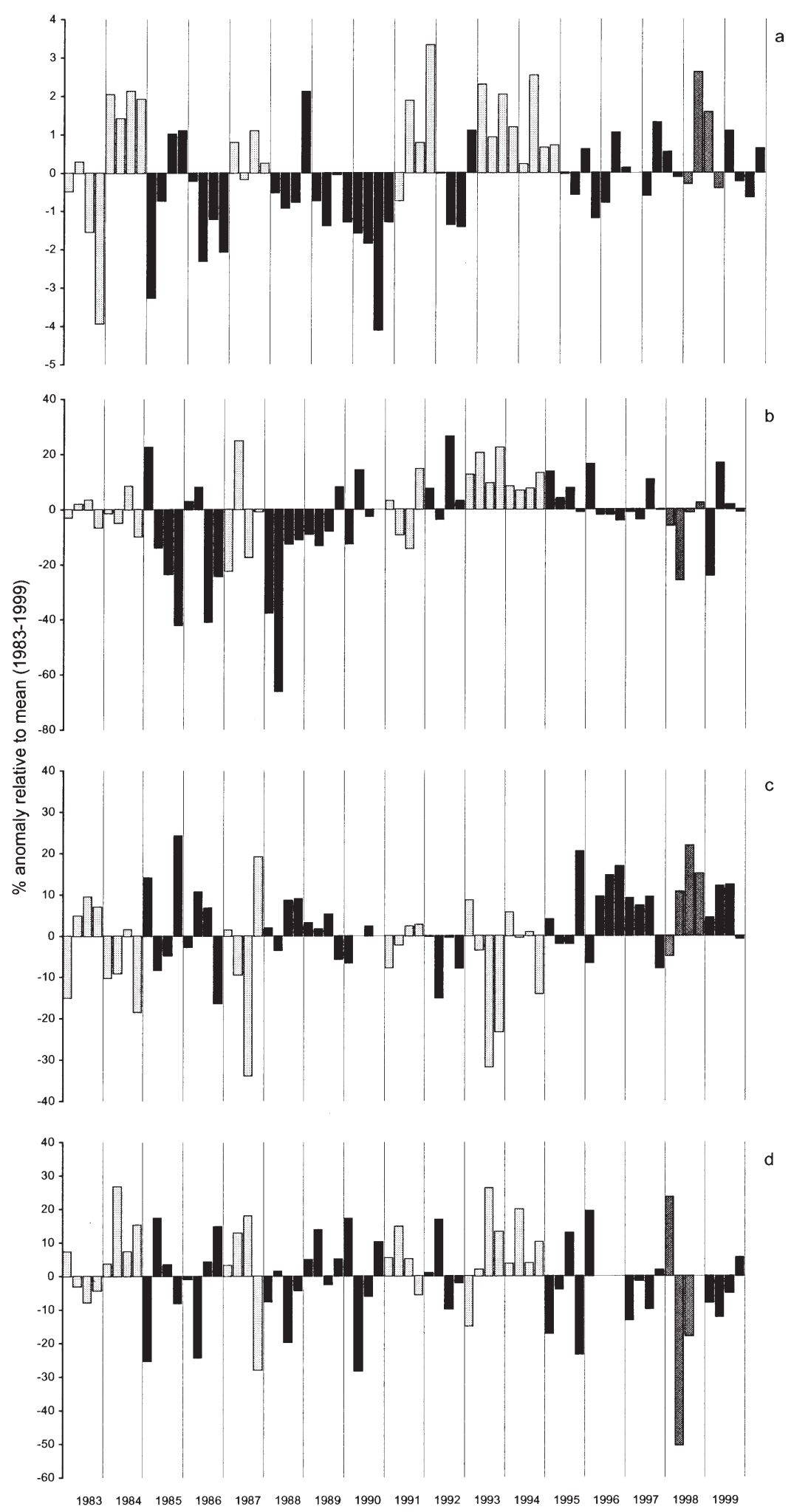

Fig. 2. Meteorological record for Tahiti. Anomalies shown for (a) sea surface temperature (SST), (b) wind speed, (c) cloud cover, and (d) sun hours, based on the 1983 to 1999 monthly means for January to April. Years where bleaching was reported in French Polynesia are shaded black, no bleaching years are shaded light grey, and 1998 is shaded dark grey most accurate model included all 3 variables and was insensitive to whether 1993 was categorised as a mass bleaching event or not. In short, the interactive effect of cloud cover reversed a statistical prediction of mass bleaching in 1998 based on cumulative SST anomalies with and without wind speed (Table 1).

\section{DISCUSSION}

Previous studies have suggested that threshold levels of sea temperature may predict bleaching events in the Society Islands. Hoegh-Guldberg \& Salvat (1995) found that a monthly mean of hourly temperature at a depth of $14 \mathrm{~m}$ was associated with the onset of bleaching in 1994. Temperatures exceeded $29^{\circ} \mathrm{C}$ in 1994 but were below this threshold during the 'non-bleaching' years 1992 and 1993 (although they concede that weak bleaching was observed in 1993). A more detailed analysis (HoeghGuldberg 1999) used weekly SST records to predict that bleaching events would occur when mean weekly temperature exceeded $29.2^{\circ} \mathrm{C}$. Whilst the paucity of bleaching in 1998 appears to contradict the use of this 'threshold' because both in situ and mean monthly SST measurements exceeded $29.2^{\circ} \mathrm{C}$, it is difficult to evaluate such thresholds objectively. Firstly, thresholds have a specific temporal scale which may not be conserved between data sets. Thus, the weekly data of Hoegh-Guldberg \& Salvat (1995) may not be directly comparable to data analysed by hour, day or month. Secondly, thresholds require a temporal duration identifying how long the threshold must be exceeded before bleaching will occur. Such a duration is not available for French Polynesia. Thirdly, the absolute accuracy of temperature measurements may differ between data sets, in which case the magnitude of anomalies may be more informative. It should be pointed out, however, that the baseline from which anomalies are calculated is critical and must be conserved between studies. In the present study, anomalies were calculated against mean monthly values 


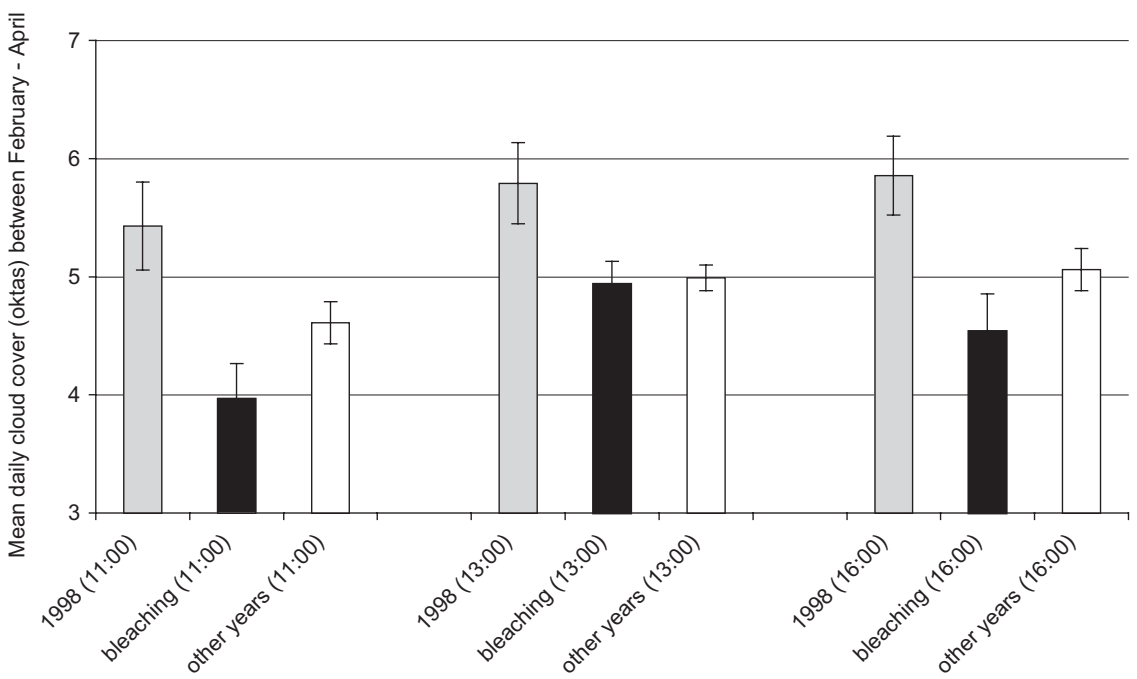

Fig. 3. Mean daily cloud cover (95\% CI) between February and April. Cloud data presented for 1998 (shaded), bleaching years (solid), and all years except 1998 for which data exist (open). Data for 11:00 and 16:00 h based on 1993 to 1999, whereas data for 13:00 to $14: 00 \mathrm{~h}$ based on 1983 to 1990

between 1983 and 1999. Although SST anomalies are doubtless a useful predictor of bleaching events at large scales (e.g. Goreau \& Hayes 1994, Strong et al. 1998, Wilkinson et al. 1999), SST anomalies alone do not predict the occurrence of bleaching events in the Society Islands. If they did, mass bleaching would have occurred in 1998 as predicted by the quadratic discriminant analysis and Hoegh-Guldberg's analysis of SST thresholds (Hoegh-Guldberg 1999).

From February to April 1998 there was significantly greater cloud cover than previous years for which data were available. These cloudy conditions appear to have occurred throughout the day in the critical months of 1998 and therefore we suggest that solar radiation was not only reduced in total, but it is likely that maximum midday irradiance was also reduced. The results of discriminant analyses show that cloud cover may interact with other environmental variables to radically alter the prediction of bleaching. It should be borne in mind that the discriminant function was weighted favourably towards SST having a predominant predictive control on bleaching. This is because data were analysed only for periods of anomalously high SST, degree heating months were used rather than mean SST, and the discriminant function was derived from all years apart from 1998 so that this anomalous year did not bias the results obtained. Thus, we suggest that for the magnitude of SST anomalies reported for the Society Islands, reduced radiative stress may have prevented large-scale coral bleaching during the 1998 ENSO. Such empirical conclusions are consistent with the model predictions of Jones et al. (1998), who suggested that shading of reefs may prevent the occurrence of bleaching during periods of elevated SST.

The year 1983 did not fit the 'elevated temperaturedecreased cloud cover' model of bleaching closely. In 1983, cloud cover was slightly higher than the 1983 to 1999 average for 3 summer months and sun hours showed an inverse pattern. It is likely, however, that 1983 was an unusual bleaching year in that the 1982/1983 ENSO caused significant depression of sea level, which increased the penetration of solar radiation and caused increased thermal warming, particu-

Table 1. Quadratic discriminant analysis predicting the onset of bleaching from cumulative positive sea surface temperature (SST) anomalies $\left({ }^{\circ} \mathrm{C}\right)$, mean wind speed $\left(\mathrm{m} \mathrm{s}^{-1}\right)$, and mean cloud cover (oktas) during periods of positive SST anomaly. Overall accuracy of (discriminant) function is calculated from the total number of correct bleaching/non-bleaching assignments from training data. This is not an independent assessment of accuracy but indicates the fit of the model to the input data. Bleaching years were 1983, 1984, 1987, 1991, 1993, and 1994. The analysis was repeated with 1993 set to 'non mass-bleaching' since this was clearly a mild bleaching year (Drollet et al. 1994). The correct prediction for 1998 was non mass-bleaching, a term which encompasses very mild bleaching such as annual bleaching and the localised observations from 1998

\begin{tabular}{|c|c|c|c|c|}
\hline & Bleaching years & SST & SST + Wind & SST + Wind + Cloud \\
\hline \multirow{2}{*}{$\begin{array}{l}\text { Overall accuracy of } \\
\text { function }(\%)\end{array}$} & Not 1993 & 77 & 77 & 92 \\
\hline & All & 92 & 92 & 92 \\
\hline \multirow{2}{*}{$\begin{array}{l}\text { Years confused in } \\
\text { training data }\end{array}$} & Not 1993 & $1983,1987,1993$ & 1983, 1987, 1993 & 1994 \\
\hline & All & 1987 & 1987 & 1987 \\
\hline \multirow{2}{*}{$\begin{array}{l}\text { Prediction of } \\
\text { bleaching for } 1998\end{array}$} & Not 1993 & Incorrect & Incorrect & Correct \\
\hline & All & Incorrect & Incorrect & Correct \\
\hline \multirow{2}{*}{$\begin{array}{l}\text { Confidence of } \\
\text { prediction }(\%)\end{array}$} & Not 1993 & 54 & 62 & $>99.9$ \\
\hline & All & $>99.9$ & $>99.9$ & $>99.9$ \\
\hline
\end{tabular}


larly in shallow water associated with reef crests where most of the mortality was observed (Salvat; cited in Glynn 1984). Although the 1998 ENSO was more severe than that of 1982/1983 (Wilkinson et al. 1999), sea level only showed minor fluctuations $(22 \mathrm{~mm})$ in French Polynesia (W. C. Patzert, NASA Jet Propulsion Laboratory, pers. comm.).

The role of wind speed in bleaching events remains equivocal. A number of studies have made anecdotal remarks that bleaching often followed calm periods (reviewed in Glynn 1993). Calm conditions may favour bleaching if water clarity, and hence light transmittance, is high and calm seas may reduce specular reflection (Hendee 1998). However, wind speeds in the Society Islands were on average higher than normal in several bleaching years, particularly 1987, 1993 and 1994. Further, wind speeds were extremely low during 1998 which, like elevated SST, are usually perceived to be highly conducive to bleaching. We suggest that wind may have a more complicated role for high islands such as Tahiti and Moorea, as high wind speeds may facilitate the removal of clouds and hence enhance the overall transmittance of solar radiation.

Two alternative explanations for the paucity of bleaching in 1998 are possible but there is currently insufficient evidence that either apply to the coral genera or locations studied here. Firstly, Rowan et al. (1997) demonstrated that 3 clades of zooxanthellae in the Caribbean coral Montastraea annularis differed in their susceptibility to bleaching. Conceivably, bleaching may act as a selection regime in which more resistant clades of zooxanthellae replace pre-bleaching clades (the 'adaptive bleaching hypothesis', Buddemeier \& Fautin 1993). Secondly, Brown et al. (2000) found that west-facing sides of Goniastrea colonies, which experienced higher solar irradiance from January to March than east-facing sides, had greater tolerance to bleaching when SST increased in May. They suggested that the history of exposure to solar radiation may effect subsequent susceptibility to bleaching. Whether this mechanism holds for a wider number of genera, physical conditions, and over longer periods is unclear. Whilst neither explanation can be discounted at this stage, the meteorological data provide a much simpler explanation of the temporal pattern of bleaching in the Society Islands. Although the cloud cover associated with high islands may have been adequate to prevent mass bleaching in the Society Islands, patterns of cloud cover may partly account for spatial patchiness in bleaching intensity and/or bleachinginduced mortality in other areas. We suggest that coral reef monitoring programmes consider the incorporation of cloud cover so that the synergies of SST and irradiance in determining mass coral bleaching might become clearer.
Acknowledgements. P.J.M. was funded by a Royal Society University Research Fellowship. We thank the UK Meteorological Office for access to data from Tahiti, and B. Salvat, Y. Chancerelle, J. Algret (CRIOBE), and V. Prasil (Service des Resources Marines) are thanked for generously providing temperature data on various islands. B. Salvat is also thanked for his comments on the manuscript. This work was made possible by the extraordinary generosity of Prince Khaled bin Sultan bin Abdulaziz of Saudi Arabia, who made available the logistical facilities of his vessel, the MY 'Golden Shadow'. We are most grateful to the captains and crews of the Golden Fleet for their professional efficiency and kindness. Barbara Brown and Richard Dunne are also thanked for useful discussions on bleaching, temperature and cloud cover. Three referees improved an earlier version of the manuscript.

\section{LITERATURE CITED}

Brown BE (1997) Coral bleaching: causes and consequences. Coral Reefs 16:S129-138

Brown BE, Suharsono NOWE (1990) Damage and recovery of coral reefs affected by El Niño related seawater warming in the Thousand Islands, Indonesia. Coral Reefs 8:163-170

Brown BE, Dunne RP, Chansang H (1996) Coral bleaching relative to elevated seawater temperature in the Andaman Sea (Indian Ocean) over the last 50 years. Coral Reefs 15:151-152

Brown BE, Ambarsari I, Warner ME, Fitt WK, Dunne RP, Gibb SW, Cummings DG (1999) Diurnal changes in photochemical efficiency and xanthophyll concentrations in shallow water reef corals: evidence for photoinhibition and photoreception. Coral Reefs 18:99-105

Brown BE, Dunne RP, Goodson MS, Douglas AE (2000) Bleaching patterns in reef corals. Nature 404:142-143

Buddemeier RW, Fautin DG (1993) Coral bleaching as an adaptive mechanism. BioScience 43:320-326

Davies JM, Dunne RP, Brown BE (1996) Coral bleaching and elevated sea-water temperature in Milne Bay Province, Papau New Guinea, 1996. Mar Freshw Res 48:513-516

Drollet JH, Faucon M, Martin PMV (1994) A survey of environmental physico-chemical parameters during a minor coral mass bleaching event in Tahiti in 1993. Mar Freshw Res 45:1149-1156

Drollet JH, Faucon M, Martin PMV (1995) Elevated sea-water temperature and solar UV-B flux associated with two successive coral mass bleaching events in Tahiti. Mar Freshw Res 46:1153-1157

Falkowski PG, Jokiel PL, Kinzie RA (1990) Irradiance and corals. In: Dubinski Z (ed) Ecosystems of the world, 25: coral reefs. Elsevier, Amsterdam, p 89-107

Fisk DA, Done TJ (1985) Taxonomic and bathymetric patterns of bleaching in corals, Myrmidon Reef, Queensland. Proc 5th Int Coral Reef Symp 6:149-154

Fitt WK, Warner ME (1995). Bleaching patterns of four species of Caribbean reef corals. Biol Bull 189:298-307

Gleason DF, Wellington GM (1993) Radiation and coral bleaching. Nature 365:836-838

Gleason MG (1993) Effects of disturbance on coral communities: bleaching in Moorea, French Polynesia. Coral Reefs 12:193-201

Glynn PW (1984) Widespread coral mortality and the 1982/83 El Niño warming event. Environ Conserv 11:133-146

Glynn PW (1993) Coral reef bleaching: ecological perspectives. Coral Reefs 12:1-17

Goreau TJ, Hayes RL (1994) Coral bleaching and ocean 'hotspots'. Ambio 23:176-180 
Harriott VJ (1985) Mortality rates of scleractinian corals before and during a mass bleaching event. Mar Ecol Prog Ser 21:81-88

Hendee JC (1998) An expert system for marine environmental monitoring in the Florida Keys National Marine Sanctuary and Florida Bay. In: Brebbia CA (ed) Proc 2nd Int Conf on Environmental Coastal Regions. Computational Mechanics Publications WIT Press, Southampton, p 57-66

Hoegh-Guldberg O (1999) Climate change, coral bleaching, and the future of the World's coral reefs. Mar Freshw Res 50:839-866

Hoegh-Guldberg O, Salvat B (1995) Periodic mass-bleaching and elevated sea temperatures: bleaching of outer reef slope communities in Moorea, French Polynesia. Mar Ecol Prog Ser 121:181-190

Iglesias-Prieto R (1997) Temperature-dependent inactivation of phosystem II in symbiotic dinoflagellates. Proc 8th Int Coral Reef Symp 2:1313-1318

International Society for Reef Studies (1998) ISRS Statement on bleaching. Reef Encounter 24:19-20

Jones RJ, Hoegh-Guldberg O, Larkum AWL, Schreiber U (1998) Temperature induced bleaching of corals begins with impairment of dark metabolism in zooxanthellae. Plant Cell Environ 21:1219-1230

Lesser MP (1996) Elevated temperatures and ultraviolet radiation cause oxidative stress and inhibit photosynthesis in symbiotic dinoflagellates. Limnol Oceanogr 41:271-283

Lesser MP (1997) Oxidative stress causes coral bleaching during exposure to elevated temperatures. Coral Reefs 16:187-192

Lesser MP, Stochaj WR, Tapley DW, Shick JM (1990) Bleaching in coral reef anthozoans: effects of irradiance, ultraviolet radiation and temperature, on the activities of protective enzymes against active oxygen. Coral Reefs 8: $225-232$

Minitab (1997) Minitab Users Guide. Minitab Inc, PA

Mumby PJ, Chisholm JRM, Edwards AJ, Clark CD, Roark EB, Andrefouet S, Jaubert J (2001) Unprecedented bleachinginduced mortality in Porites spp. at Rangiroa Atoll, French Polynesia. Mar Biol 139:183-189

Editorial responsibility: Otto Kinne (Editor), Oldendorf/Luhe, Germany
Osmond CB (1994) What is photoinhibition? Some insights from comparisons of shade and sun plants. In: Baker NR, Bower JR (eds) Photoinhibition of photosynthesis. Bios Scientific Publishers, Oxford, p 1-24

Parker DE, Folland CK, Jackson M (1995) Marine surface temperature: observed variations and data requirements. Clim Change 31:559-600

Rayner NA, Horton EB, Parker DE, Folland CK, Hackett RB (1996) Version 2.2 of the Global Sea-Ice and Sea Surface Temperature data set, 1903-1994. Climate Research Technical Note No. 74. Hadley Centre for Climate Prediction and Research, Meteorological Office, Bracknell

Reynolds RW (1988) A real-time global sea surface temperature analysis. J Climatol 1:75-86

Rowan R, Knowlton N, Baker A, Jara J (1997) Landscape ecology of algal symbionts creates variation in episodes of coral bleaching. Nature 388(6639):265-269

Salvat B (1992) Blanchissement et mortalité des scléractiniaires sur les récifs de Moorea (archipel de la Société) en 1991. CR Acad Sci Paris 314(3):105-111

Smith TM, Reynolds RW, Livezey RE, Stokes DC (1996) Reconstruction of historical sea surface temperatures using empirical orthogonal functions. J Climatol 9: 1403-1420

Strong AE, Goreau TJ, Hayes RL (1998) Ocean hotspots and coral reef bleaching. January-July 1998. Reef Encounter 24:20-21

Warner ME, Fitt WK, Schmidt GW (1996) The effects of elevated temperature on the phosynthetic efficiency of zooxanthellae in hospite from four different species or reef coral: a novel approach. Plant Cell Environ 19:291-299

Wilkinson C (2000) Status of coral reefs of the World: 2000. Australian Institute of Marine Science, Townsville

Wilkinson C, Linden O, Cesar H, Hodgson G, Rubens J, Strong AE (1999) Ecological and socioeconomic impacts of 1998 coral mortality in the Indian Ocean: an ENSO impact and a warning of future change? Ambio 28:188-196

Winter A, Appeldoorn RS, Bruckner A, Williams EH, Goenaga C (1988) Sea surface temperatures and coral reef bleaching off La Parguera, Puerto Rico (northeastern Caribbean Sea). Coral Reefs 17:377-382

Submitted: August 10, 2000; Accepted: March 21, 2001

Proofs received from author(s): October 18, 2001 